\title{
PERBANDINGAN HASIL BELAJAR MATEMATIKA SISWA KELAS IV YANG MENGIKUTI DENGAN YANG TIDAK MENGIKUTI BIMBINGAN BELAJAR
}

\section{OLEH:}

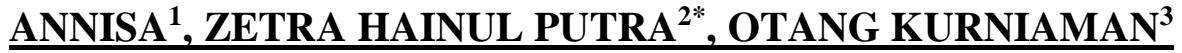 (UNIVERSITAS RIAU ${ }^{1,2,3}$ )}

\begin{abstract}
The purpose of this study is to compare the learning outcomes of fourth grade students between students who take tutoring and non-tutoring. This study also looks for students' motivation for participating in tutoring after school. Students' learning outcomes and motivation are evaluated based on five categories; very low, low, medium, high, and very high categories. The method used in this research is quantitative descriptive. This research was conducted on 98 students from a public elementary school in Pekanbaru. The instruments used to collect data are objective test questions on the material of 2D shapes, statistics and angle measurements as well as questionnaires about students' motivation to follow tutoring. The results of this study indicate that the learning outcomes of students who take tutoring are better than students who do not follow tutoring, and students'motive to participate in tutoring was to obtain better learning outcomes. The implication of this research is that parents need to consider their children to attend tutoring,otherwise schools need to think and design learning that can improve student learning outcomes.
\end{abstract}

Keywords: learning outcomes; learning motivation; mathematics; tutoring.

\section{PENDAHULUAN}

Pendidikan matematika di tanah air saat ini mengalami perubahan paradigma. Terdapat kesadaran yang kuat, terutama dikalangan pengambil kebijakan, untuk memperbaharui pendidikan matematika. Pendidikan matematika di sekolah dasar memiliki tujuan yang sangat penting yaitu untuk melatih siswa dalam memecahkan permasalahan yang berkaitan dengan hitungan. Menurut National Research Council (Cowan, 2006), dalam rangka mengembangkan pemikiran matematika dan kemampuan untuk memecahkan masalah, siswa perlu untuk "melakukan" matematika. Hal ini berarti bahwa siswa perlu 
menggabungkan kegiatan seperti memecahkan masalah yang menantang, memahami pola, merumuskan dugaan dan memeriksanya, menarik kesimpulan melalui penalaran serta mengkomunikasikan ide-ide, pola, dugaan dan kesimpulan tersebut. Berdasarkan pendapat tersebut, matematika penting dan harus dikuasai oleh siswa secara komprehensif dan holistik, artinya bahwa pembelajaran matematika sebaiknya mengoptimalkan keberadaan dan peran siswa sebagai pelajar.

Dalam pembelajaran matematika, para siswa dibiasakan untuk memperoleh pemahaman melalui pengalaman tentang sifat-sifat yang dimiliki dan yang tidak dimiliki dari sekumpulan objek (abstraksi). Siswa diberi pengalaman menggunakan matematika sebagai alat untuk memahami atau menyampaikan informasi misalnya melalui persamaan-persamaan, atau tabel-tabel dalam modelmodel matematika yang merupakan penyederhanaan dari soal-soal cerita atau soalsoal uraian matematika lainnya. Namun, proses pembelajaran matematika siswa tidak selalu berjalan dengan lancar, kemudian secara umum permasa lahan belajar menurut Thahir dan Hidriyanti (2014) yaitu tidak adanya motivasi untuk belajar matematika yaitu keadaan siswa yang tidak semangat dalam belajar, lambatnya menerima pembelajaran matematika serta kebiasaan kurang baik dalam belajarnya seperti menunda-nunda buat tugas, membenci guru dan tak acuh. Sehingga, banyak siswa yang beranggapan bahwa pembelajaran matematika ini adalah mata pelajaran yang sulit dipelajari dan sering juga dikatakan pelajaran yang menakutkan, hal ini banyak dialami oleh siswa yang mengakibatkan rendahnya hasil belajar siswa dalam pelajaran matematika, hal ini sesusai dengan sindrom psikologis berupa learning disability (ketidak mampuan belajar) yang 
berarti adanya keabnormalan psikis yang menimbulkan kesulitan belajar yang salah satunya adalah Diskalkulia yaitu ketidakmampuan belajar matematika, kesulitan belajar siswa yang menderita sindrom tersebut hanya disebabkan oleh adanya gangguan ringan pada otak (Syah, 2003). Salah satu upaya yang dapat dilakukan dalam mengatasi hal tersebut yaitu mengikuti bimbingan belajar. Bimbingan perlu dilakukan karena termasuk ke dalam bagian terpenting yang dapat menunjang pendidikan.

Seiring dengan perkembangan zaman dan dengan semakin meningkatnya daya kompetensi antar siswa serta semakin tingginya tuntutan lapangan terhadap kualitas pendidikan, maka saat ini banyak lembaga bimbingan yang muncul seperti bimbingan belajar diluar jam pelajaran sekolah serta mendatangkan guru kerumah / private bahkan di era modern sekarang ini bimbingan belajar dapat ditemui di aplikasi handphone dan lainnya. Bimbingan belajar merupakan program bantuan yang diberikan kepada individu yang tujuannya untuk membantu siswa dalam menghadapi dan memecahkan masalah dalam hal belajarnya serta untuk meningkatkan prestasi belajarnya. Para pembimbing membantu individu atau siswa mengatasi kesulitan belajar, mengembangkan cara belajar yang efektif, membantu individu agar sukses dalam belajar supaya mampu menyesuaikan diri terhadap semua tuntunan program atau pendidikan (Yusuf \& Nurihsan, 2010).

Menurut Hamalik (2004) bimbingan belajar adalah bimbingan yang ditujukkan kepada siswa untuk mendapat pendidikan yang sesuai dengan kebutuhan, bakat, minat, kemampuannya dan membantu siswa untuk menentukan cara-cara yang efektif dan efisien dalam mengatasi masalah belajar yang dialami oleh siswa. Tujuan pelayanan bimbingan belajar secara umum adalah membantu 
murid-murid agar mendapatkan penyesuaian yang baik di dalam situasi belajar, sehingga setiap murid dapat belajar dengan efisien sesuai kemampuan yang dimilikinya, mencapai perkembangan yang optimal (Ahmadi \& Widodo, 2004). Jadi, dapat disimpulkan bahwa bimbingan belajar merupakan program bantuan yang diberikan kepada individu yang tujuannya untuk membantu siswa dalam menghadapi dan memecahkan masalah dalam hal belajarnya serta untuk meningkatkan prestasi belajarnya.

Hasil riset yang dilakukan oleh Amelia (2017) menunjukan bahwa siswa sebelum mengikuti bimbingan belajar termasuk dalam kategori rendah yaitu 48,84 sedangakan hasil tes setelah mengikuti bimbingan belajar menunjukkan adanya peningkatan yaitu 69,4 maka, kesimpulan penelitiannya bahwa bimbingan belajar ini memiliki pengaruh tehadap hasil belajar siswa. Hasil belajar adalah kemampuan yang dimiliki siswa setelah terjadi proses belajar mengajar yang dipengaruhi oleh faktor dari dalam diri siswa dan faktor yang datang dari luar diri siswa atau faktor lingkungan. Faktor yang datang dari diri siswa terutama kemampuan yang dimilikinya. Faktor kemampuan siswa besar sekali pengaruhnya terhadap hasil belajar yang dicapai (Sudjana 2009). Berdasarkan teori Taksonomi Bloom (dalam Daryanto,2007) hasil belajar dalam rangka studi dicapai melalui tiga kategori ranah antara lain kognitif, afektif, dan psikomotorik.

Didalam bimbingan belajar terdapat berbagai mata pelajaran yang diajarkan kepada siswa yang mengikutinya. Peserta didik yang mengikuti salah satu bimbingan menganggap bimbingan yang mereka ikuti selama ini yang terbaik termasuk pendapat orang tua mereka, bahwa anaknya pintar karena mengikuti bimbingan yang selama ini diikuti anaknya dan mendapatkan hasil yang 
memuaskan. Apalagi dengan adanya bimbingan belajar yag muncul dimana-mana yang tujuanya untuk membantu siswa mengahadapi permasalahan belajarnya. Tetapi kenyataannya banyak kita lihat sekarang ini nilai yang terbaik yang diperoleh para siswa di sekolah diraih oleh siswa yang tidak ada mengikuti bimbingan belajar, melainkan belajar sendiri dirumahnya. kemudian bimbingan belajar ini memiliki peran sebagai saran bagi siswa untuk memperoleh bantuan dalam kesulitan.

Motivasi dapat menjadi faktor pendorong siswa untuk mengikuti bimbingan belajar. Menurut Purwanto (dalam Eriany dkk, 2014) Motivasi adalah suatu usaha yang disadari untuk mempengaruhi tingkahlaku seseorang agar dia tergerak hatinya untuk bertindak melakukan sesuatu sehingga mencapai hasil atau tujuan tertentu sedangkan menurut Mc. Donald (dalam Sardiman, 2004) motivasi adalah perubahan energi dalam diri seseorang yang ditandai dengan munculnya "feelling" dan didahului dengan tanggapan terhadap adanya tujuan. Dari pengertian yang dikemukakan oleh Mc. Donald ini maka timbul element penting, meliputi: 1. Bahwa motivasi itu mengawali terjadinya perubahan energi pada diri setiap individu manusia. Perkembangan motivasi akan membawa beberapa perubahan energi didalam system "neurophysiological" yang ada pada organisme manusia. Karena menyangkut perubahan energi manusia (walaupun motivasi ini muncul dari dalam diri manusia), penampakannya akan menyangkut kegiatan fisik manusia. 2. Motivasi tumbuh dengan ditandai dengan munculnya, rasa/eellin, afeksi seseorang. Dalam hal ini motivasi relevan dengan persoalan persoalan kejiwaan, afeksi dan emosi yang dapat menentukan tingkah laku manusia. 3. Motivasi akan dirangsang karena adanya tujuan. 
Hasil riset yang dilakukan oleh Legowo (2016) bahwa ada kaitan antara layanan bimbingan belajar dengan motivasi belajar. Artinya semakin baik dan efektif pemberian layan bimbingan belajar terhadap siswa makan semakin tinggi motivasi belajar siswa, sebaliknya semakin kurang efektif pemberian layanan bimbingan belajar pada siswa maka semakin rendah motivasi velajar siswa. Hasil penelitian tersebut diperkuat pendapat Bahri (dalam Miftahillah, 2014) yang mengemukakan ada 2 faktor yang menentukan pencapaian hasil belajar yaitu: faktor internal dalam hal motivasi belajar dan faktor eksternal yaitu bimbingan belajar. Dengan demikian jika bimbingan belajar semakin tinggi dan motivasi belajar juga semakin tinggi, maka akan semakin tinggi pula prestasi belajar yang dicapai.

Berdasarkan problematika yang telah dijelaskan tersebut, maka peneliti mengakaji mengenai perbandingan hasil belajar siswa yang mengikuti bimbingan belajar dengan siswa yang tidak mengikuti khususnya matapelajaran matematika tingkat SD kelas IV, serta bagaimanakah motivasi siswa mengikuti bimbingan belajar tersebut. Tujuan dari penilitian ini adalah untuk mengetahui hasil belajar siswa yang mengikuti bimbingan belajar dengan siswa yang tidak mengikuti khususnya materi matematika dan mengetahui motivasi siswa yang mengikuti bimbingan belajar.

\section{METODE PENELITIAN}

Jenis penelitian ini adalah penelitian komparatif. Penelitian ini dilakukan untuk membandingkan persamaan dan perbedaan dua fakta-fakta dan sifat-sifat objek yang diteliti berdasarkan kerangka pemikiran tertentu. 
Subjek dalam penelitian ini adalah 98 siswa kelas IV dari sebuah sekolah dasar negeri di Pekanbaru. Metode yang digunakan dalam penlitian ini adalah metode deskriptif kuantitatif. Alat yang digunakan peneliti untuk mengukur hasil belajar yaitu dengan cara tes tulisan dalam bentuk objektif yang memiliki 3 indikator yaitu konsep, keterampilan dan pemecahan masalah. Kemudian untuk non tes yaitu menggunakan angket skala likert untuk mengetahui motivasi siswa yang mengikuti bimbingan belajar. Langkah pertama yang diambil oleh peneliti adalah menyiapkan instrument penelitian dalam bentuk tes soal objektif yaitu sebanyak 25 soal, kemudian untuk angket sebagai hasil tes pendukung yang terdiri dari 25 butir pernyataan.

Teknik analisis data yang digunakan untuk menguji hasil belajar siswa yang mengikuti dengan yang tidak mengikuti bimbingan belajar yaitu menggunakan analisis data kuantitatif. Data diperoleh dari hasil tes soal objektif mengenai bangun datar, statistika dan pengukuran sudut dengan menggunakan 3 indikator yaitu konsep, keterampilan dan pemecahan maslah. Skor yang digunakan adalah jika jawaban benar diberi skor 1 dan jawaban salah diberi skor 0. Skor yang telah diperoleh dari hasil tes kemudian dikonversi ke nilai di kisaran 0-100. Semua hasil tes dihitung menggunkan statistik deskriptif, kemudian dianalisis secara deskriptif dan diambil kesimpulannya. Data dari kemampuan hasil belajar siswa dikelompokkan berdasarkan kategori-kategori pada tabel 1.

Tabel 1. Kategori penilaian hasil belajar

\begin{tabular}{|c|c|}
\hline Nilai & Kategori \\
\hline $0 \leq \mathrm{X}<25$ & Sangat Rendah \\
\hline $25 \leq \mathrm{X}<45$ & Rendah \\
\hline $45 \leq \mathrm{X}<65$ & Sedang \\
\hline
\end{tabular}




\begin{tabular}{|c|c|}
\hline $65 \leq \mathrm{X}<85$ & Tinggi \\
\hline $85 \leq \mathrm{X} \leq 100$ & Sangat Tinggi \\
\hline
\end{tabular}

Setelah masing-masing siswa dikategorikan menurut hasil tesnya, kemudian peneliti akan membuat tabel distribusi frekuensi agar data yang telah dikumpulkan dalam jumlah banyak dapat disajikan dalam bentuk yang jelas dan baik. Selain itu tabel distribusi frekuensi dibuat untuk menyederhanakan bentuk dan jumlah data sehingga ketika data disajikan akan lebih mudah dipahami.

Untuk variabel angket siswa yang mengikuti bimbingan belajar matematika, jawaban setiap pernyataan diberi skor dengan kriteria penskoran skala likert yang telah dimodifikasi, respon atas pernyataan yaitu skor 1 sampai dengan 4 , lebih jelas pada tabel 2 .

Tabel 2. Skor berdasarkan skala Likert

\begin{tabular}{|c|c|c|}
\hline Jawaban & Skor Pernyataan Positif & Skor Pernyataan Negatif \\
\hline Sangat Setuju (SS) & 4 & 1 \\
\hline Setuju (S) & 3 & 2 \\
\hline Tidak Setuju (TS) & 2 & 3 \\
\hline $\begin{array}{c}\text { Sangat Tidak Setuju } \\
\text { (STS) }\end{array}$ & 1 & \\
\hline
\end{tabular}

Kemudian data hasil angket ini dikelompokkan berdasarkan rata-rata yang memiliki 5 kategori dapat dilihat pada tabel 3.

Tabel 3. Penentuan kategori rata-rata siswa yang mengikuti bimbingan belajar

\begin{tabular}{|c|c|}
\hline Kategori & Interval Rata-rata Skor \\
\hline Sangat Rendah & $1 \leq \mathrm{X}<1,5$ \\
\hline Rendah & $1,5 \leq \mathrm{X}<2$ \\
\hline Sedang & $2 \leq \mathrm{X}<2,5$ \\
\hline Tinggi & $2,5 \leq \mathrm{X}<3$ \\
\hline Sangat Tinggi & $3 \leq \mathrm{X}<4$ \\
\hline
\end{tabular}


Untuk analisis statistik inferensial yang digunakan untuk menganalisis data sampel dan hasilnya diberlakukan untuk populasi. Langkah pertama yaitu melakukan uji normalitas yang tujuan untuk melihat sampel berdistribus normal atau tidak, penelitian ini menggunakan Kolmogorof-smirnov, jika Jika Dhitung < Ktabel maka variabel berdistribusi normal. Berdasarkan perolehan hasil D0 0,115 $<$ Ktabel 0,210 maka dapat disimpulkan bahwa data kedua variabel berdistribusi normal. Selanjutnya, untuk uji homogenitas menggunakan uji barlet. Jika Xhitung > Xtabel maka variabel tidak homogen begitu sebaliknya jika Jika Xhitung < Xtabel maka variabel homogen. Brdasarkan hasilnya X2 hitung 1,40 < X2Tabel 7,82, maka dapat disimpulkan bahwa dari data tersebut homogen.

Setelah dilakukan uji normalitas dan uji homogenitas bartlet, selanjutnya dilakukan uji perbedaan rata-rata. Uji perbedaan rata-rata bertujuan untuk menentukan apakah hasil matematika yang mengikuti bimbingan belajar dan yang tidak mengikuti bimbingan belajar berbeda, dengan kriteria jika thitung > ttabel dengan $\mathrm{dk}=(\mathrm{n} 1+\mathrm{n} 2-2)$ dan taraf nyata 0,05 maka $\mathrm{H} 0$ ditolak.

\section{HASIL DAN PEMBAHASAN}

\section{HASIL}

\section{Hasil Belajar Matematika Siswa yang Mengikuti Bimbingan Belajar}

Hasil belajar belajar matematika siswa yang mengikuti bimbingan belajar berdasarkan hasil tes soal objektif yang memiliki 3 indikator yaitu, konsep, keterampilan dan pemecahan masalah, masing-masing indikator memiliki 3 materi kelas IV yaitu materi mengenai Bangun datar, Statistika dan Pengukuran sudut. Kemudian dilakukan penskoran yang dikonveksikan menjadi nilai dan 
diklasifikasikan kedalam 5 kategori yaitu sangat rendah, rendah, sedang, tinggi dan sangat tinggi. Hasil belajar siswa berdasarkan 3 indikator disajikan pada Diagram 1.

Diagram 1. Hasil kemampuan siswa yang mengikuti bimbingan belajar

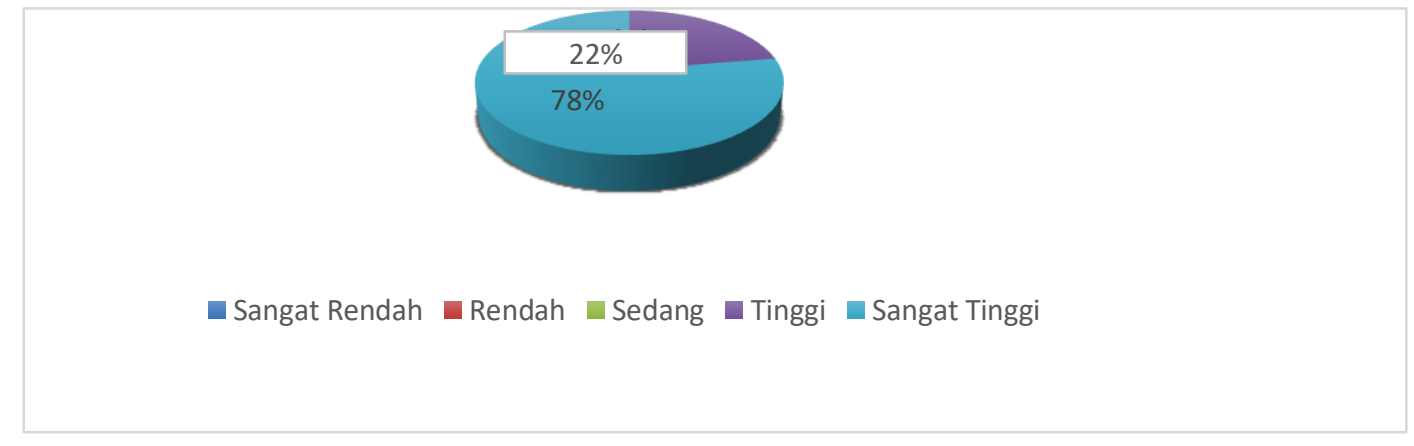

Berdasarkan Diagram 1, setelah dianalisis hasil belajar siswa yang mengikuti bimbingan belajar menunjukkan $78 \%$ siswa mendapatkan kategaori sangat tinggi. Kemampuan siswa yang mengikuti bimbingan belajar ini mendapat rata-rata sebesar 89,24. Berdasarkan rata-rata, keseluruhan kemampuan siswa yang mengikuti bimbingan belajar matematika mendapatkan kategori sangat tinggi.

\section{Hasil Belajar Matematika Siswa yang Mengikuti Bimbingan Belajar berdasarkan Indikator Konsep}

Kemampuan mengemukakan kembali ini terdapat 3 materi pelajaran matematika kelas IV semester 2 yaitu bangun datar, statistika dan pengukuran sudut. Jawaban tes berdasarkan indikator konsep secara keseluruhan siswa kelas IV disajikan pada Diagram 2. 


\section{Diagram 2. Hasil belajar siswa mengikuti bimbel secara keseluruhan pada indikator konsep}

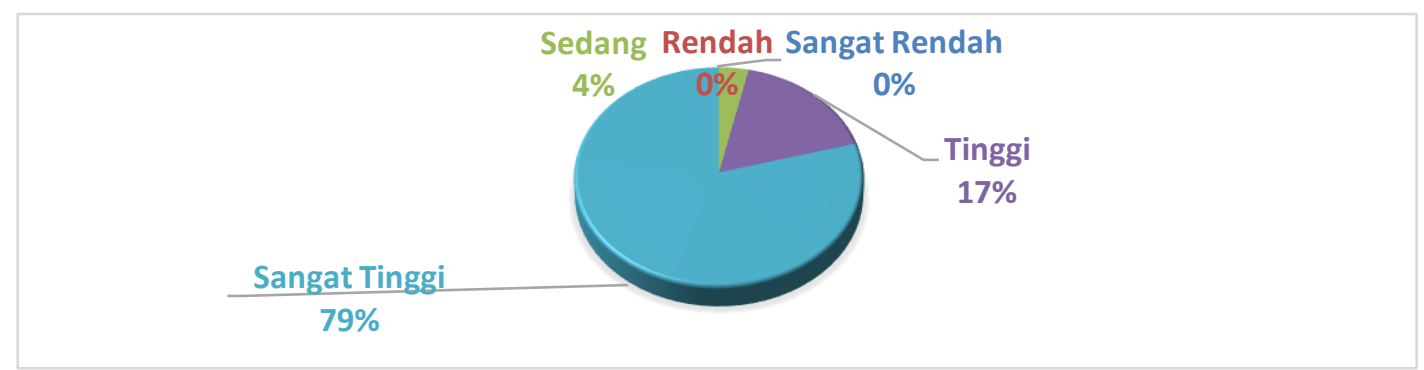

Berdasarkan Diagram 2, siswa yang mendapatkan kategori sangat tinggi lebih banyak daripada siswa yag mendapatkan kategori sedang. Rata-rata siswa pada indikator ini 92,16 yang mendapat kategori sangat tinggi.

\section{Hasil Belajar Matematika Siswa yang Mengikuti Bimbingan Belajar berdasarkan Indikator Keterampilan (Prosedural)}

Indikator procedural dalam matematika ini menunjukkan kemampuan siswa dalam menyelesaikan masalah sesuai dengan langkah-langkah. Didalam indikator procedural ini terdapat 3 materi yaitu bangun datar, statistika dan pengukuran sudut. Kemampuan menyelesaikan masalah secara sistematis jawaban tes secara keseluruhan siswa kelas IV yang mengikuti bimbingan belajar dapat dilihat pada Diagram 3.

\section{Diagram 3. Hasil belajar siswa mengikuti bimbel secara keseluruhan pada indikator keterampilan}

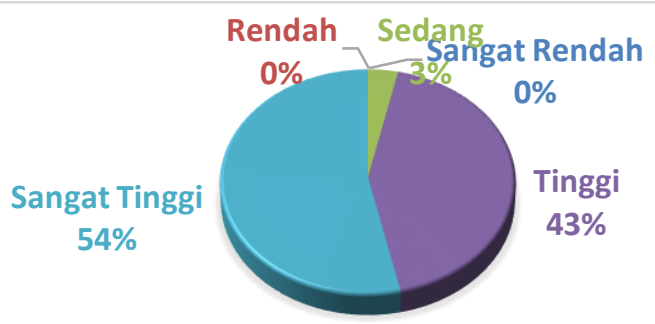


Berdasarkan Diagram 3, siswa dengan kategori sangat tinggi memiliki persentase 54\% lebih. Pada diagram tersebut terdapat siswa yang menduduki kaategori sedang dengan persentase $3 \%$. Nilai rata-rata hasil belajar matematika pada indikator procedural secara keseluruhan yaitu sebesar $84,31 \%$ artinya ratarata hasil belajar siswa mendapatkan kategori tinggi.

\section{Hasil Belajar Matematika Siswa yang Mengikuti Bimbingan Belajar berdasarkan Indikator Pemecahan Masalah}

Pada indikator ini siswa harus mampu memahami masalah terlebih dahulu, kemudian siswa mampu memecahkan masalah dan siswa dapat menarik kesimpulan dari permasalahan berdasarkan lagkah penyelesaiannya. Didalam indikator ini terdapat 2 materi yaitu bangun datar dan statistika. Kemampuan indikator pemecahan masalah secara keseluruhan siswa kelas IV yang mengikuti bimbingan belajar dapat dilihat pada Diagram 4.

\section{Diagram 4. Hasil belajar siswa mengikuti bimbel secara keseluruhan pada indikator pemecahan masalah}

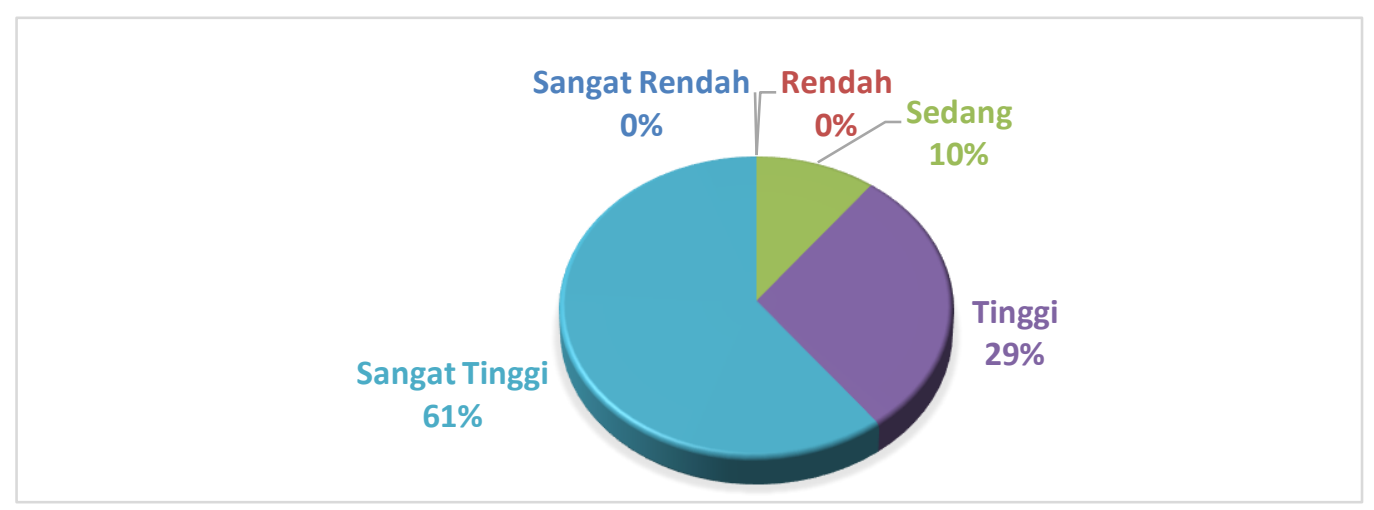

Berdasarkan Diagram 4, siswa yang menempati kategori sangat tinggi dengan persentase $61 \%$. Pada diagram tersebut terdapat siswa yang mendapatkan kategori sedang dengan persentase $10 \%$. Nilai rata-rata kemampuan hasil belajar siswa 
secara keseuruhan berdasarkan indikator pemecahan masalah yaitu sebesar 87,5 yang mana rata - rata tersebut dalam kategori sangat tinggi.

\section{Hasil Belajar Matematika Siswa yang Tidak Mengikuti Bimbingan Belajar}

Sama halnya dengan siswa yang mengikuti bimbingan belajar pada kemampuan hasil siswa yang tidak mengikuti bimbingan belajar juga memiliki 3 indikator, berikut kemampuan hasil belajar siswa secara keseluruhan terlihat pada Diagram 5.

Diagram 5. Hasil belajar siswa yang tidak mengikuti bimbingan belajar

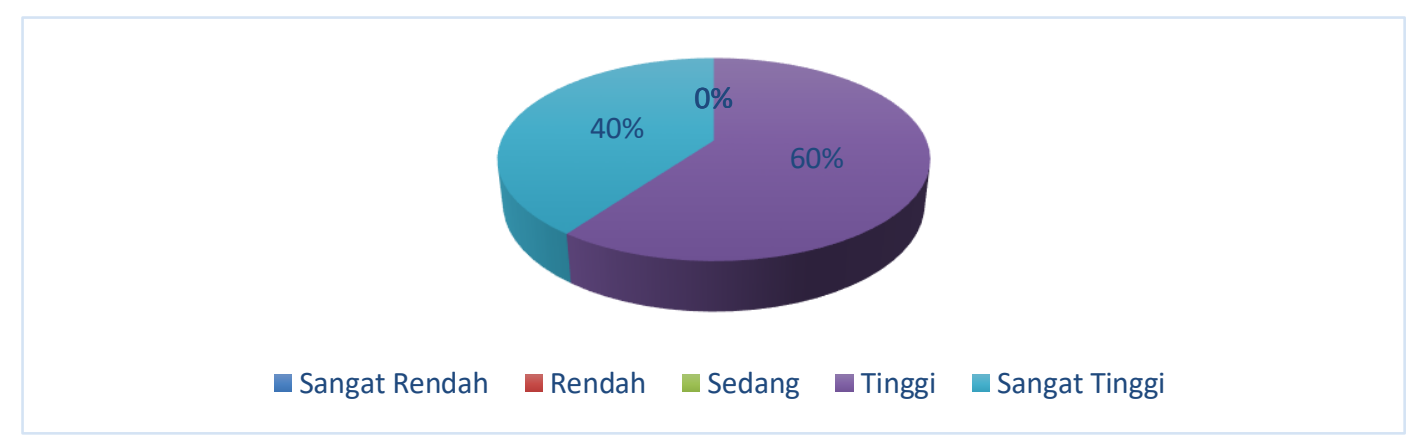

Berdasarkan Diagram 5, hasil belajar matematika siswa yang tidak mengikuti bimbingan belajar setelah dianalisis dengan menggunakan kategori terlihat hanya $40 \%$ siswa mendapatkan kategori sangat tinggi. Hasil belajar matematika siswa yang mengikuti bimbingan belajar secara keseluruhan mendapatkan rata-rata hanya 64,2 yang termasuk kategori sedang.

\section{Hasil Belajar Matematika Siswa yang tidak Mengikuti Bimbingan Belajar berdasarkan Indikator Konsep}

Hasil belajar siswayang tidak mengikuti bimbingan belajar berdasarkan indikator konsep dengan kategori sangat tinggi hanya 20\% (Diagram 6). Nilai 
rata-rata kemampuan hasil belajar matematika siswa yang tidak mengikuti bimbingan belajar yaitu 76,36 yang mendapati kategori tinggi.

\section{Diagram 6. Hasil Belajar Siswa yang tidak Mengikuti Bimbingan Belajar}

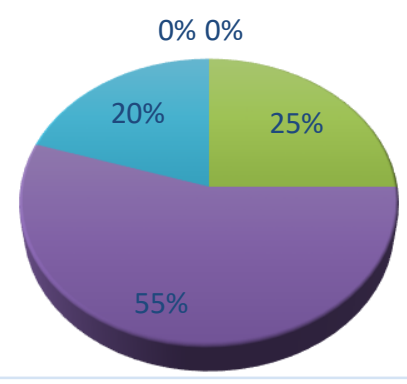

Sangat Rendah

घendah

Sedang

a Tinggi

¿ Sangat Tinggi

Hasil Belajar Matematika Siswa yang tidak Mengikuti Bimbingan Belajar berdasarkan Indikator Keterampilan

Hasil belajar siswayang tidak mengikuti bimbingan belajar berdasarkan indikator keterampilan yang menduduki kategori sangat tinggi mendapatkan persentase paling kecil yaitu hanya $8 \%$ dari $100 \%$ dan yang mendapatkan persentase paling tinggi pada kategori sedang yaitu 50\% (Diagram 11). Rata-rata siswa yang tidak mengikuti bimbingan belajar berdasarkan indikator keterampilan secara keseluruhan adalah 60 yang termasuk kategori sedang.

\section{Diagram 7. Hasil Belajar siswa tidak mengikuti bimbel secara keseluruhan pada indikator keterampilan}

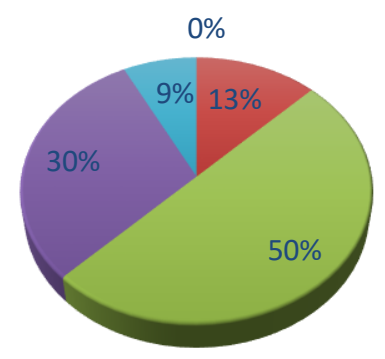

$$
\begin{aligned}
& \text { Sangat Rendah } \\
& \text { Rendah } \\
& \text { Sedang } \\
& \text { a Tinggi } \\
& \text { Sangat Tinggi }
\end{aligned}
$$




\section{Hasil Belajar Matematika Siswa yang tidak Mengikuti Bimbingan Belajar berdasarkan Indikator Pemecahan Masalah}

Hasil belajar siswayang tidak mengikuti bimbingan belajar berdasarkan indikator pemecahan masalahyang menempati kategori sangat tinggi hanya $8 \%$ (Diagram 13). Pada diagram diatas 32\% siswa yang mendapatkan kategori rendah. Nilai rata - rata kemampuan hasil belajar siswa yang tidak mengiktu bimbingan belajar secara keseuruhan berdasarkan indikator pemecahan masalah yaitu haya 51,25 yang mana rata - rata tersebut dalam kategori sedang.

\section{Diagram 8. Kemampuan siswa tidak mengikuti bimbel secara keseluruhan pada indikator pemecahan masalah}

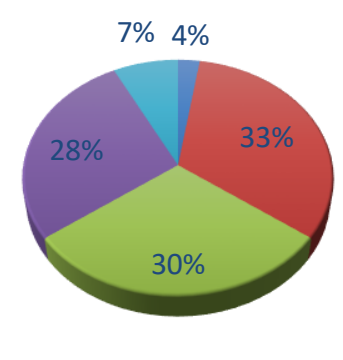

$$
\begin{aligned}
& \text { Sangat Rendah } \\
& \text { Rendah } \\
& \text { a Sedang } \\
& \text { a Tinggi } \\
& \text { a Sangat Tinggi }
\end{aligned}
$$

\section{Hasil Angket Terhadap Siswa yang Mengikuti Bimbingan Belajar}

Angket ini bertujuan untuk mengetahui motivasi siswa yang mengikuti bimbingan belajar. Angket ini diperoleh berdasarkan faktor-faktor yang mempengaruhi motivasi yaitu pola permintaan, tujuan siswa, fungsi megikuti bimbingan belajar, sifat mengikuti bimbingan belajar, perolehan hasil belajar dan kesesuaian mata pelajaran matematika. Skala siswa yang mengikuti bimbingan belajar dengan empat pilihan jawaban yaitu dengan skor 1-4 disebarkan kepada 58 siswa. Rata-rata minimal yang diperoleh responden adalah 2,76 dan rata-rata maksimal yang diperoleh responden adalah 3,84. Hasil rata-rata tersebut 
dilakukan pengkategorian data angket siswa yang mengikuti bimbingan belajar. Dari analisis data, diperoleh hasil pengelompokkan tinggi rendahnya rata-rata jawaban siswa terhadap variabel angket siswa yang mengikuti bimbingan belajar dapat dilihat pada Diagram 9.

Diagram 9. Hasil Angket Motivasi Siswa Mengikuti Bimbingan Belajar

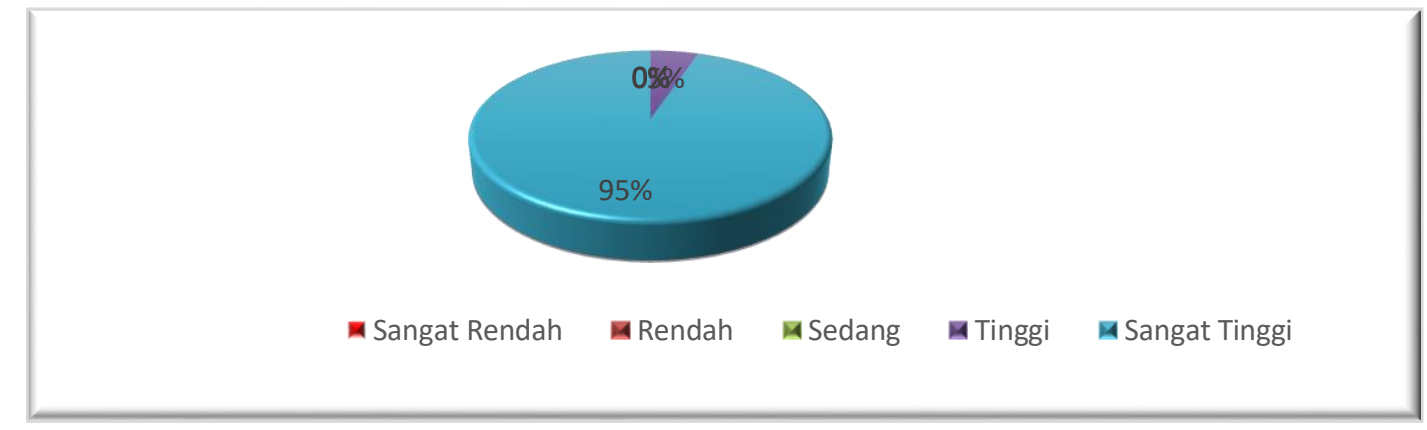

Berdasarkan Diagram 9, maka dapat diketahui bahwa 55 siswa degan perentase tertinggi yaitu $95 \%$ yang mendapatkan kategori sangat tinggi dan pada kategori tinggi terdapat 3 orang siswa dengan persentase 5\%. Dari tabel diatas menunjukkan bahwa pada siswa kelas IV SD Negeri 6 Pekanbaru termotivasi untuk mengikuti bimbingan belajar khususnya pada matapelajaran matematika. Hal ini dibuktikan dengan mendapati kategori sangat tinggi yang memiliki jumlah persentase tertinggi.

\section{PEMBAHASAN}

Hasil belajar matematika siswa yang mengikuti maupun yang tidak mengikuti dinilai dari 3 indikator yaitu konsep, keterampilan dan pemecahan masalah. Dengan menganalisa 3 indikator, dapat dilihat persentase kemampuan siswa kelas IV SDN 6 Pekanbaru, serta rekapitulasi siswa. Dari hasil analisis secara keseluruhan siswa yang mengikuti bimbingan belajar termasuk kategori 
sangat tinggi dengan rata-rata 89,24. Berdasarkan ketiga indikator tersebut, indikator konsep dengan rata-rata tertinggi yaitu 92,16 sedangkan yang terendah pada indikator keterampilan yaitu 84,31 . Untuk kemampuan siswa yang tidak mengikuti bimbingan belajar dengan rata-rata 64,2 yang termasuk kategori sedang. Pada indikator pemecahan masalah mendapatkan rata-rata terendah yaitu 51,25 yang memiliki jumlah soal 4 butir soal dan paling tinggi pada indikator konsep yaitu 76,36 dengan 11 butir soal.

Selanjutnya uji perbedaan rata-rata menggunakan uji-t yang tujuannya untuk menentukan apakah hasil matematika yang mengikuti bimbingan belajar dan yang tidak mengikuti bimbingan belajar itu berbeda, yang mana thitung 19,07 > ttabel 1,664 yang berarti H0 ditolak dan H1 diterima. Maka, dapat disimpulkan bahwa ada perbedaan hasil belajar siswa yang mengikuti bimbingan belajar dengan siswa yang tidak mengikuti bimbingan belajar pada kelas IV SD Negeri 6 Pekanbaru.

Dengan adanya hasil siswa mengikuti bimbingan belajar ini diperkuat dengan hasil angket yang diisi oleh siswa yang menunjukkan 95\% siswa yang termotivasi mengikuti bimbingan belajar karena kinginan siswa untuk memperoleh hasil belajar yang maksimal dan memperoleh pengetahuan yang lebih dan karena siswa ingin memantapkan pemahaman materi belajar khususnya pada matapelajaran matematika yang dipelajarinya di kelas IV SD Negeri 6 Pekanbaru. Dalam penelitian Afiananda (2018) mengatakan bahwa motivasi dapat berfungi sebagai pendorong usaha dalam pencapaian prestasi. Seseorang siswa melakukan suatu usaha karena adanya motivasi. Adanya motivasi yang baik dalam belajar akan menunjukan hasil yang baik pula. Dengan kata lain bahwa adanya usaha yang tekun dan terutama disadari adanya motivasi, maka seseorang 
yang belajar itu akan dapat melahirkan prestasi yang baik. Intensitas motivasi seseorang siswa akan sangat menentukan tingkat pencapaian prestasi belajarnya.

Menurut Hamalik (dalam Nurrahmi, 2017), bimbingan belajar adalah bimbingan yang ditunjukkan kepada siswa untuk mendapat pendidikan yang sesuai dengan kebutuhan, bakat, minat, kemampuannya dan membantu siswa untuk menentukan cara-cara efektif dan efisien dalam mengatasi masalah belajar yang dialami siswa. Kemudian sebagian besar siswa yang mengikuti bimbingan belajar ini melakukan latihan setelah pembelajarannya selesai, tujuannya agar siswa terbiasa dengan masalah dalam hal belajarnya untuk mencapai hasil yang lebih optimal. Hal ini sesuai dengan teori belajar E. Thorndike yang salah satunya adalah Hukum Latihan (law of exercise), yaitu semakin sering suatu tingkah laku diulang/dilatih maka asosiasi tersebut semakin kuat (Amsari \& Mudjiran, 2018).

Dengan adanya bimbingan belajar ini dapat meningkatkan kinerja siswa di sekolah karena siswa merasa mendapatkan informasi dan dapat membangun konsep lebih awal dari proses interaksi di suatu bimbingan belajar. Hal ini sesuai dengan teori konstruktivisme yang dipaparkan oleh piaget bahwa pengetahuan yang dimiliki siswa merupakan pengetahuan yang dibangun berdasarkan pemahaman siswa sendiri. Pengetahuan siswa dapat dibangun dari proses interaksi dengan lingkungan belajarnya termasuk dari lembaga bimbingan belajar dengan teman sebaya. Semakin luas interaksi yang terjadi maka siswa akan semakin banyak memperoleh informasi untuk mendukung pengetahuannya. Proses konstruksi pengetahuan dan lingkungan belajarnya dapat menjadikan belajar lebih bermakna sehingga tujuan pembelajaran dapat tercapai (Nurrahmi, 2017). 


\section{PENUTUP}

Berdasarkan hasil dan pembahasan maka diperoleh bahwa hasil belajar siswa yang mengikuti bimbingan belajar pada kelas IV dikategorikan sangat tinggi dengan rata-rata 89,24. Diantara ketiga indikator tersebut indikator konsep yang paling tinggi dan paling rendah pada indikator keterampilan. Sedangkan kemampuan hasil belajar siswa yang tidak mengikuti bimbingan belajar dengan rata-rata 64,2. Indikator tertinggi yang dicapai oleh siswa yang tidak mengikuti yaitu pada indikator konsep dan yang terendah pada indikator pemecahan masalah. Siswa yang mengikuti bimbingan belajajar ini diperkuat dengan adanya angket yang merupakan perkembangan hasil belajarnya yaitu 95\% siswa yang mengikuti bimingan belajar mendapatkan hasil belajar yang meningkat dan lebih memahami ilmu matematika yang dipelajarinya.

Implikasi dari penelitian ini yaitu orang tua perlu mempertimbangkan untuk mengikutkan anaknya dibimbingan belajar atau berperan serta dalam membantu dan membimbing anaknya selama belajar dirumah. Disisi lain, guru perlu merancang pembelajaran yang menyenangkan yang mampu meningkatkan hasil belajar matematika dan diharapkan kepada guru-guru dapat menghimbau siswa yang mengikuti bimbingan belajar matematika agar lebih serius dan bersungguhsungguh dalam mengikuti bimbingan belajar sehinga dapat meningkatkan lagi hasil belajar matematikanya. Lestari, Syahrilfuddin, Putra, dan Hermita (2019) dalam studinya menemukan bahwa pembelajaran berdasarkan Pendidikan Matematika Realistik mampu meningkatkan motivasi belajar siswa, sehingga pendekatan tersebut perlu dipertimbangkan guru dalam pembelajaran 


\section{DAFTAR PUSTAKA}

Ahmadi, A., \& Widodo, S. (2004). Psikologi Belajar. Jakarta: PT Rineka Cipta.

Amsari, D., \& Mudjiran. (2018). Implikasi Teori Belajar E.Thorndike (Behavioristik) dalam Pembelajaran Matematika. Jurnal BASICEDU: Jurnal of Elementary Education, 2(2), 52-60.

Cowan, P. (2006). Teaching mathematics: A hand book for primary school and secondary school teacher. New York: Routledge.

Daryanto. (2018). Evaluasi Pendidikan. Jakarta: Rineka Cipta.

Eriany, P., Hernawati, L., \& Georitno, H. (2014). Studi Deskriptif Mengenai Faktor-Faktor yang Mempengaruhi Motivasi Mengikuti Kegiatan Bimbingan Belajar pada Siswa SMP di Semarang. PSIKODIMENSIA: Kajian Ilmiah Psikologi, 13(1), 115-130.

Firdayanti, D. (2019). Perbandingan Antara Hasil Belajar Matematika Siswa yang Mengikuti dengan yang tidak Mengikuti Bimbingan Belajar Di Kelas IV SD Negeri 29 Banda Aceh.FKIP Universitas Syiah Kuala.Banda Aceh. https://etd.unsyiah.ac.id/index.php?p=show_detail\&id=60802

Hamalik, O. (2004). Proses Belajar Mengajar. Jakarta: Bumi Aksara.

Legowo, L. L. (2016). Hubungan Layanan Bimbingan Belajar dengan Motivasi Belajar siswa Kelas VII SMP Negeri 4 Sentolo.FKIP Universitas Negeri Yogyakarya, http://repository.upy.ac.id/1384/

Lestari, S., Syahrilfuddin, Putra, Z., \& Hermita, N. (2019). The Effect of Realistic Mathematic Approach on Students' Learning Motivation. Journal of Teaching and Learning in Elementary Education, 2(2), 145-156.

Miftahillah. (2014). Hubungan Antara Bimbingan Belajar dan Motivasi belajar dengan Prestasi Belajar Siswa di MI Nidhomiyah Jombang. MODELING: Jurnal Program studi PGMI, 2(2), 139-156.

Nurrahmi, F. (2017). Pengaruh Keikutsertaan Siswa Mengikuti Bimbingan Belajar terhadap Hasil Belajar Ekonomi di Kelas XII IPS SMA Negeri 5 Depok Tahun Ajaran 2016/2017. Skripsi tidak dipublikasikan.http://repository.uinjkt.ac.id/dspace/handle/123456789/3863 5

Sardirman. (2004). Interaksi \& Motivasi Belajar Mengajar. Jakarta: PT Raja Grafindo Persada. 
Sudjana, N. (2009). Dasar-dasar Proses Belajar Mengajar. Bandung: Sinar Baru Algensindo.

Syah, M. (2003). Psikologi Belajar. Jakarta: PT Raja Grafindo Persada.

Yusuf, S., \& Nurihsan, A. (2010). Landasan Bimbingan dan Konseling. Bandung: PT Remaja Rosdakarya. 